\title{
腎と眼窩にみとめた pseudolymphoma
}

札幌医科大学泌尿器科学教室（主任：熊本悦明教授）

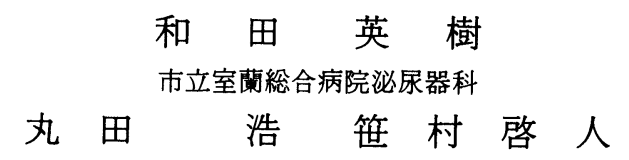

A CASE REPORT OF PSEUDOLYMPHOMA OF THE KIDNEY AND ORBIT

\author{
Hideki Wada \\ Department of Urology, Sapporo Medical College \\ (Director: Prof. Yoshiaki Kumamoto) \\ Hiroshi Maruta and Hiroto Sasamura \\ Department of Urology, Muroran General Hospital
}

\begin{abstract}
Pseudolymphoma is reactive extranodal lymphocytosis, and it's lymphocytes are so minimally atypical that it is basically benign. The patient was a 68 -year-old female with pain in the left back and lower abdomen. Plain CT (computerized tomogram) of the kidney revealed a mass in the left kidney. It had a smooth surface and higher density than parenchyma. Similarly a left orbital mass was revealed by CT. We could not deny the mass to be a malignant tumor, so we took specimens from these lesions by an open biopsy. Histological examination of these specimens showed pseudolymphoma. Pseudolymphoma of the left kidney was reduced in its size by treatment with prednisolone. The patient is continuously followed up to date.
\end{abstract}

Key words: pseudolymphoma, kidney, orbit

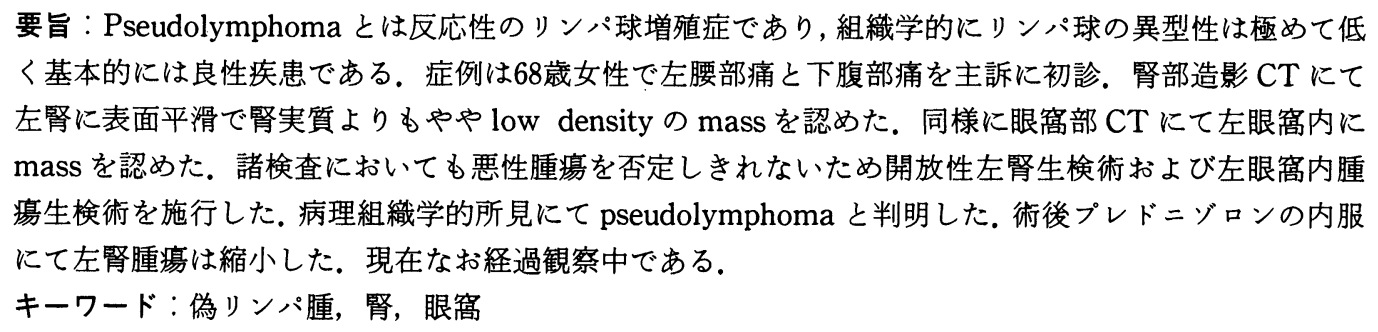

\section{䋖}

Pseudolymphoma とは反応性のリンパ球増殖症で あり, 組織学的にはリンパ球の異型性は極めて低く基 本的には良性疾患である。その発生部位は皮唐，消化 管，肺，眼窩など様々であるが，泌尿器科領域で組織 学的に確認しえた報告は我々の調べた限り膀胱 ${ }^{1)}$ 之後 腹膜到にそれぞれ 1 例ずつのみである.今回我々は左 腎と左眼窩内に同時に発生した pseudolymphoma を 経験したので報告する。

患者: 68歳, 女性.
主訴 : 左腰部痛, 下腹部痛.
家族歷：特記すべきことなし。

既往歴：30歳時, 子宮後屈にて手術. 41歳時, 両側 乳腺症にて手術。60歳頃不整脈を指摘されていたが放 置していた。

現病歴：1989年 4 月， 8 月， 9 月と急性腎孟腎炎を 繰り返し,某医にて入院治療を受けた。精査目的に1989 年10月 2 日市立室蘭総合病院泌尿器科初診.

初診時検查所見: 検血, 血液生化学にとくに異常は なかった。血清免疫グロブリン值にも異常はなかった。 検尿では RBC $1 \sim 3 / \mathrm{F}, \mathrm{WBC} 0 \sim 1 / \mathrm{F}$ を認める以外異 常所見はなかった。理学的には前胸部に発疹を認める 以外異常所見はなかった。 
図 1 治療前腎部造影 CT

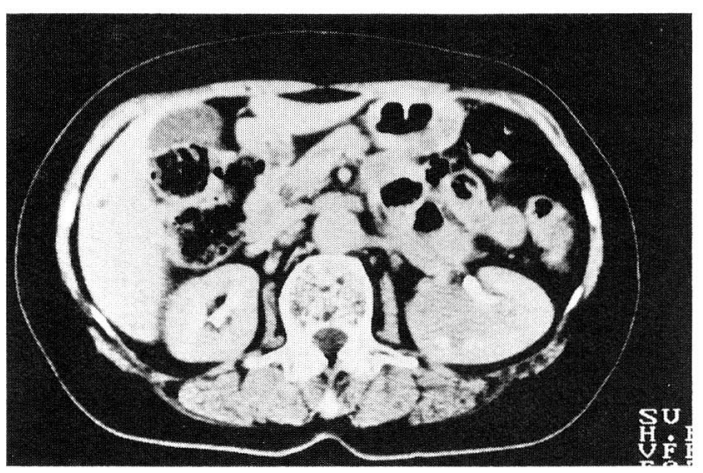

因 2 治療前眼窩部プレーンCT

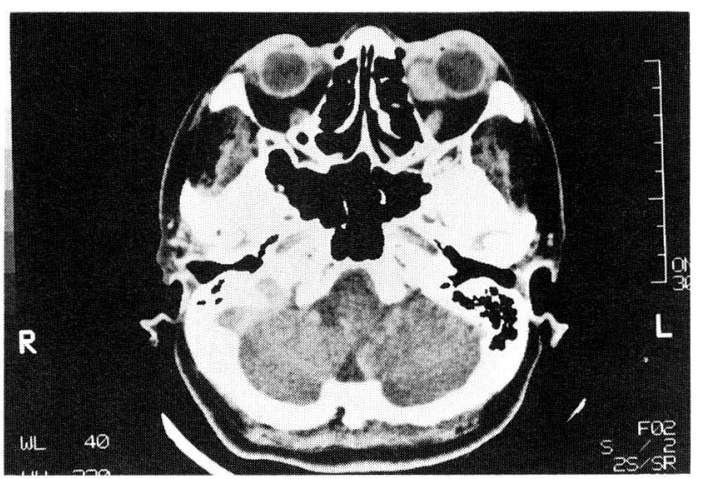

排尿性膀脱尿道造影ではVURを認めなかった。 IVPで左上腎杯の拡張と左腎孟の陰影欠損を認めた ため, 逆行性腎孟造影を施行したところ左腎孟の変形, 狭窄を認めた。腎孟尿細胞診は陰性であった。そこで 腎部造影 CT を施行したところ左腎孟を圧排するやや low densityの mass を認めた（図 1).

この後 CT にて経過観察をしていたが腎腫瘍の可能 性を否定できないため，1990年 8 月31日入院のうえ精 査となった。

入院後経過：腎動脈造影では normo-vascularであ り, 明らかな悪性を疑わせる所見を認めなかった。左 眼の異和感を認めたため眼窩部プレーンCT を施行し たところ左眼窩内々側部に high density の腫瘤を認 めた（図 2).

手術所見：1991年 1 月23日，これまでの検查におい ても悪性腫瘍を否定しきれなかったので組織確認のた め全身麻酔下に左腎摘位にて腎に至り, 腫瘍の一部を 試験切除した。腫惶は表面平滑で乳白色を呈し堅実質 より母指頭大の大きさで突出しており尿管を挙上して
図 3 病理組織所見（胚中心と滤胞構造）( $\times 40 ）$

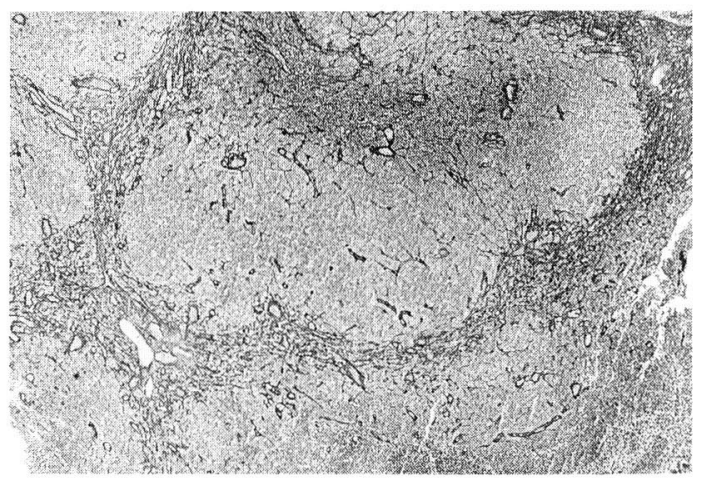

図 4 免疫グロブリン染色(右： $\varkappa$ 型, 左： $\lambda$ 型) ( $~($ 200)

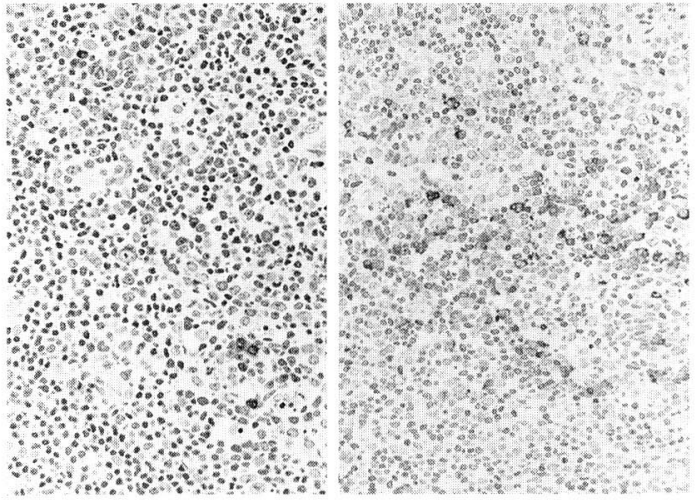

いた，割面も乳白色を呈していた．凍結病理切片にて リンパ組織様であったが悪性所見を認めなかったため 腎摘はせずに手術を終了した。2 月20日左眼窩内腫瘍 に対しても眼科で局所麻酔下に生検術を施行した。

病理組織所見：腎，眼窝いずれの組織も異型性のな い多彩なリンパ球が密に増殖浸潤して，不明瞭ではあ るが濾胞様構造, 肧中心も見られた(図 3 ). 免疫グロ ブリン染色では $\varkappa$ 型 light chain に染色されるリンパ 球が多いが $\lambda$ 型に染色されるリンパ球も存在してお り polyclonal な分布像であった(図 4).リンパ球抗原 で染色すると B-cell が優位に染色された(図 5 ). 以上 の組織学的所見より異型性のない反応性のリンパ球増 殖と考克 pseudolymphoma と診断した。

術後経過：3 月19日腎 CT 施行したが腫痬の大きさ には変化を認めなかった，病変が眼窩と腎に存在する ため放射線治療よりもステロイドの内服治療が妥当と 考完，3月26日より21日間プレドニゾロン $30 \mathrm{mg} / \mathrm{day}$ 
図 5 リンパ球抗原染色(右：T-cell 抗原，左：B-cell 抗原 $)(\times 200)$

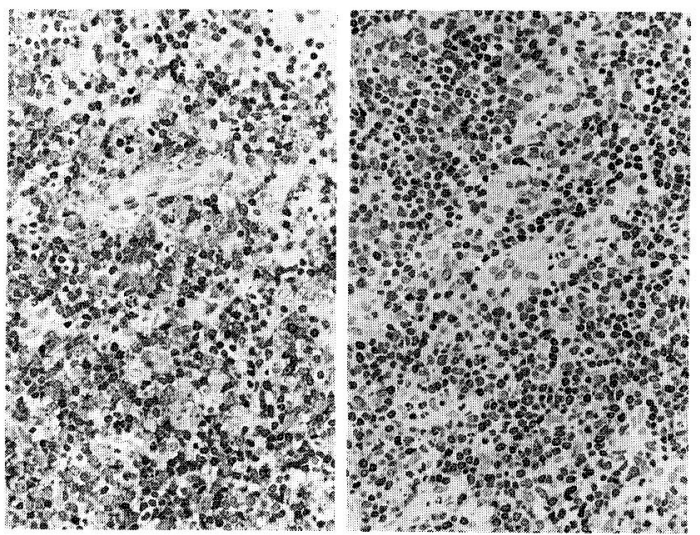

の内服を開始した.その後 $20 \mathrm{mg} /$ day を22日間, $10 \mathrm{mg} /$ dayを177日間と漸減し，同年10月31日に中止した(総 投与量 $2,840 \mathrm{mg})$. プレドニゾロン内服後48日目の腎部 造影 CT（図 6)では腫瘍の縮小を認めた。しかし，眼 窩部 CT では眼窩内腫瘍には変化がなかった。眼窩腫 瘍は1991年10月16日札幌医大眼科で腫瘍摘出を行っ た。翌1992年 3 月16日の腎 CT では腫瘍の再増殖を認 めず，患者は現在異常なく生活している。

\section{考察}

Pseudolymphomaは, その成因としては慢性炎症や 自己免疫疾患の関連が考兄られており，なた組織学的 に悪性リンパ腫と断定しかねるものなどとされ，その 疾患概念は，未だ明らかな統一がない(3)5)6)。しかし，1） リンパ節以外の部位に生じ, リンパ球の異型性は低く, 胚中心・リンパ濾胞の構造を持ち成熟リンパ球が優勢 である，2）周用に線維性反応を認める，3）さらに免 疫グロブリン染色では polyclonality4)を示し，4）
図 6 治療後腎部造影 CT

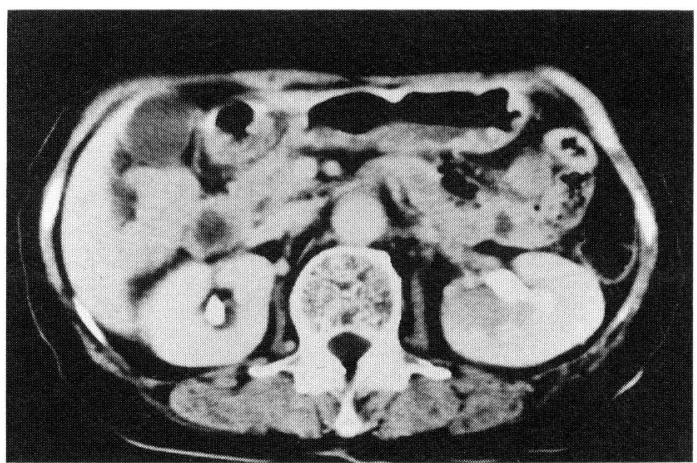

DNA 解析では diploid pattern を示すなどの特徴をも つとされている5 . これらの所見から悪性リンパ腫と 鑑別されている.

発生部位は様々であり, 消化器, 皮膚, 肺, 眼窩の 報告例は比較的多くその匡か甲状腺，唾液腺6とど も発生したという報告もある。しかし，泌尿器科領域 での報告はわれわれが調べた限りでは1984年に末定 ら 2)が報告した後腹膜に発生した pseudolymphoma と1989年に吉永ら ${ }^{1)}$ が報告した膀脱 pseudolymphoma, また河野ら な多臓器に pseudolymphoma 認めたシェーグレン症候群の 1 例を報告し, 両側腎に も病変を認めたとしているが組織学的には確認してい ない. 腎に発生した pseudolymphoma で組織学的に 確認し得たのは自験例が 1 例目と思われる.

腎に発生する充実性病変の中で，とくに鑑別が重要 と思われる疾患の CT と動脈造影の特徵的所見を表 1 に示した。しかし，腎癌を除いてこれらを正確に鑑別 することは困難であり自験例も最終的診断は生検に よってなされた。

Pseudolymphomaの治療は放射線治療 ${ }^{8}$ や自験例

表 1 腎の充実性病変における CT と動脈造影での鑑別点

\begin{tabular}{|c|c|c|}
\hline & $\mathrm{CT}$ & 動 脈 造 影 \\
\hline 腎＼cjkstart癌 & $\begin{array}{c}\text { 境界不整 } \\
\text { density 不均一 }\end{array}$ & 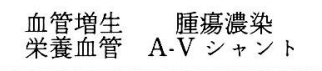 \\
\hline 血管笳脂肪腫 & fat density lesion & $\begin{array}{c}\text { 小動脈瘤 } \\
\text { onion peel appearance }\end{array}$ \\
\hline オンコサイトーマ & $\begin{array}{c}\text { 境界明瞭 } \\
\text { density 不均一 }\end{array}$ & 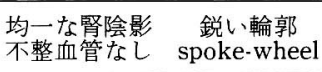 \\
\hline 黄色肉芽腫様腎監堅 & $\begin{array}{c}\text { Gerota 筋膜の肥厚 } \\
\text { density 不均一 }\end{array}$ & hypovascular or avascular \\
\hline Pseudolymphoma & $\begin{array}{c}\text { 境界明瞭 } \\
\text { density 均一 } \\
\text { やや high density }\end{array}$ & hypovascular or avascular \\
\hline
\end{tabular}


のようにステロイド投与により縮小あるいは消失した 例も報告されている9 . しかし本疾患は病理組織学的 に悪性リンバ腫との鑑別が困難であり，今後悪性变化 が起こらないか外来的に CT で注意深く経過観察しな ければならないと考えている。

\section{結 語}

左腎と左眼窩に発生を認めた pseudolymphoma を 経験したが組織学的に確認した腎の発生例は自験例が 1 例目と思われた。

稿を終えるにあたり, 病理組織学的に御教授戴いた市立 室蘭総合病院病理部藤沢泰憲先生と千葉大学医学部第一病 理学教室三方淳男先生に深謝いたします。

本論文の要旨は, 第307回日本泌尿器科学会北海道地方会 で発表した。

1）吉永英俊, 井口厚司, 真崎善二郎, 徳永 藏, 渡邊 照男: 膀脱 pseudolymphoma の 1 例. 日泌尿会 誌, 80, 899-901， 1989.

2) Suesada, Y., Nakao, N., Miura, K., Takayasu, Y., Miura, T., Taguchi, K., Ikoma, F. and Kakudo, K.: Pseudolymphoma of the Retroperitoneum. Europ. J. Radiol., 7, 144-146, 1987.

3）東原正明：Pseudolymphoma一特殊なリンパ腫 における診断と治療一. Modern Physician, 9, 212-214, 1989.
4) Julsrud, P.R., Brown, L.R., Rosenow, E.C. and Crowe, J.K.: Pulmonary process of mature appearing lymphocytes: Pseudolymphoma, Well-differentiated lymphocytic lymphoma, and lymphocytic interstitial pneumonitis. Radiology, 127, 289, 1978.

5）田中雄二, 鳥山裕史, 西野啺彦, 今野弘之, 青木克 憲, 馬場正三, 阪口周吉, 小沢亭史, 喜納 勇, 戸 倉康之：胃癌手術中に発見された空腸 pseudolymphoma. 日消外会誌，21，2643-2646， 1988.

6）鎌谷義人, 田川俊郎, 平野吉雄, 斉藤 弘, 浜口幸 洋, 村田睦男: 舌下腺にみられた pseudolymphoma の 1 例. 日ロ外誌, 34, 463-469, 1985.

7）河野恵子, 野々山智仁, 関根康生, 本村幸子, 加藤 慎二郎, 竹村博之, 新 健治, 森 尚義: 多臓器に 偽リンパ腫を認めたシェーグレン症候群の 1 例。

眼紀, 41，1055-1060， 1990.

8) Kelly, A.G., Rosas-Uribe, A. and Kraus, S.T.: Orbital lymphoma and pseudolymphomas, a clinicopathologic study of eleven cases. Am. J. Clin. Pathol., 68, 377-386, 1977.

9）橋本憲一, 赤川志のぶ, 室田直樹, 田ノ上雅彦, 大 玉信一, 千田 守, 宮里逸郎, 松原修, 田中健彦, 光永慶吉：多彩な症状を呈し, ステロイドが著効 した肺 Pseudolymphoma の 1 例。 日胸疾会誌, 23, 1194-1120, 1985.

（1992年10月 20 日受理） 